\title{
Pengaruh Continuity Of Care Terhadap Angka Kejadian Sectio Cessarea
}

\author{
Nurya Viandika, Ratih Mega Septiasari \\ STIKesWidya Cipta Husada \\ Corresponding author: Nurya Viandika (viandika04@ gmail.com) \\ Received: December, 16 2019; Accepted: January, 19 2020; Published: March, 152020
}

\begin{abstract}
ABSTRAK
Prevalensi sectio caesarea di banyak negara dari tahun ke tahun terus mengalami peningkatan, begitu pula di negara kita Indonesia sudah melebihi batas yang telah ditentukan oleh WHO. Penelitian ini bertujuan untuk mengetahui pengaruh continuity of care terhadap angka kejadian sectio secarea di PBM wilayah kerja Kabupaten Malang. Metode penelitian yang digunakan adalah eksperimen dengan design penelitian quasi experimental. Populasi penelitian yaitu semua ibu hamil TM III pada bulan Mei-Juni di daerah Kabupaten Malang. Teknik pengambilan sampel menggunakan purposive sampling, sebanyak 18 responden. Variabel independennya adalah (continuity of care) dengan variabel dependennya adalah (sectio secarea). Pengumpulan data menggunakan ceklist dan observasi. Hasil penelitian menunjukkan bahwa 94\% responden yang dilakukan continuity of care jenis persalinannya adalah normal. Analisa data dengan menggunakan uji chi-square dengan nilai $\rho=0,03$ yang berarti $\rho<\alpha, \mathrm{H} 0$ ditolak, artinya terdapat hubungan yang signifikan antara pemberian asuhan continuity of care dengan penurunan angka kejadian sectio secarea. Jadi continuity of care dapat mendeteksi dini komplikasi pada saat kehamilan sehingga dapat segera dilakukan penanganan. Oleh karena itu perlu adanya peningkatan pelayanan kebidanan terutama continuity of care kepada ibu mulai dari kehamilan, persalinan, nifas, bayi baru lahir dan keluarga berencana.
\end{abstract}

Kata Kunci: Continuity of Care, Sectio Cessarea, Kehamilan

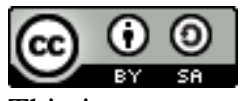

This is an open-acces article distributed under the terms of the Creative Commons Attribution-ShareAlike 4.0 International License.

\section{PENDAHULUAN}

Persalinan adalah proses pengeluaran janin dan plasenta yang telah cukup bulan atau sudah mampu hidup diluar kandungan melalui jalan lahir atau melalui jalan lain, dengan bantuan atau tanpa bantuan (kekuatan sendiri) (Marmi \& Rahardjo, 2012). Persalinan merupakan sebuah proses akhir dari serangkaian kehamilan. Terdapat dua macam proses persalinan yaitu persalinan pervaginam atau persalinan normal persalinan spontan dan persalinan sectio caesarea (SC) atau orang awam menyebutnya operasi sesar. Operasi sesar yaitu proses pengeluaran janin lewat pembedahan perut (Aprina, 2016).

Prevalensi sectio caesarea dari tahun ke tahun terus meningkat, berdasarkan data dari World Health Organization (WHO) bahwa mereka menetapkan standar rata-rata sectio 
caesarea di sebuah Negara adalah sekitar 5-15\% per 1000 kelahiran didunia. Rumah Sakit pemerintah kira-kira 11\% sementara Rumah Sakit swasta lebih dari 30\% (Gibbson, 2010). Menurut WHO peningkatan persalinan dengan sectio caesarea di seluruh Negara selama tahun 2007- 2008 yaitu 110.000 per kelahiran di seluruh Asia (Leveno, 2009).

Riskesdas tahun 2012 menyatakan tingkat persalinan sectio caesarea di Indonesia sudah melewati batas maksimal standar WHO 5-15\%. Tingkat persalinan SC di Indonesia 15,3\% sampel dari 20.591 ibu yang melahirkan dalam kurun waktu 5 tahun terakhir yng disurvey dari 33 provinsi. (Riskesdas, 2012). Jumlah persalinan sectio caesarea di Indonesia, terutama di rumah sakit pemerintah adalah sekitar 20-25\% dari total jumlah persalinan, sedangkan di rumah sakit swasta jumlahnya lebih tinggi yaitu sekitar 30-80\% dari total jumlah persalinan. Data Riskesdas 2013 menunjukkan kelahiran bedah SC di Provinsi Jawa Timur tahun 2011 berjumlah 3.401 operasi dari 170.000 persalinan, sekitar 20\% dari seluruh persalinan (Dinkes Provinsi Jawa timur, 2012).

Persalinan sectio caesarea bisa terjadi dikarenakan oleh beberapa sebab atau masalah. Masalah ini bisa berasal dari pihak ibu ataupun pihak bayi. Selain itu terdapat dua keputusan dalam pelaksanaan persalinan SC. Yang pertama adalah keputusan yang sudah didiagnosa sebelumnya atau sudah direncanakan, penyebab dari pihak bayi antara lain ketidakseimbangan ukuran kepala bayi dan panggul ibu, kelainan letak bayi, plasenta previa, janin yang sangat besar, dan gemeli (bayi kembar), sedangkan penyebab dari pihak ibu antara lain kehamilan pada ibu berusia lanjut, preeklampsia-eklampsia, riwayat bedah caesar pada kehamilan sebelumnya, ibu menderita penyakit tertentu, infeksi saluran persalinan dan sebagainya. Yang kedua adalah keputusan yang diambil tiba-tiba karena tuntutan kondisi darurat misalnya persalinan lama, ketuban pecah dini, kontraksi lemah, gawat janin dan sebagainya (Indriati, 2012). Gambaran adanya faktor resiko ibu saat melahirkan atau dioperasi sectio caesarea adalah 13,4\% karena ketuban pecah dini; 5,49\% karena preeklampsia; 5,14\% karena perdarahan; 4,40\% kelainan letak janin; 4,25\% karena jalan lahir tertutup; 2,3\% karena rahim sobek (Riskesdas, 2012).

Tindakan SC merupakan tindakan yang cepat dan mudah, akan tetapi tindakan SC juga memiliki beberapa bahaya komplikasi. Komplikasi ini diantaranya adalah kerusakan organorgan seperti vesika urinaria dan uterus saat dilangsungkannya operasi, komplikasi anastesi, perdarahan, infeksi dan tromboemboli. Kematian ibu lebih besar jika dibandingkan dengan persalinan pervaginam. Sulit untuk memastikan hal tersebut terjadi apakah dikarenakan prosedur operasinya atau karena alasan yang menyebabkan ibu hamil tersebut harus dioperasi. Selain itu takipneu sesaat pada bayi baru lahir lebih sering terjadi pada persalinan sectio caesarea dan kejadian-kejadian trauma persalinanpun tidak dapat disingkirkan. Resiko jangka panjang yang dapat terjadi adalah terjadinya plasenta previa, solusio plasenta akrata dan ruptur uteri.

Upaya yang dapat dilakukan untuk menurunkan prevalensi kejadian sectio caesarea adalah dilakukannya asuhan yang berkesinambungan atau yang biasa disebut continuity of care (COC). Continuity Of Care ini dilakukan sejak ibu pada masa kehamilan, persalinan, nifas sampai ibu menentukan pilihannya untuk memakai kontrasepsi yang akan digunakan. Asuhan kebidanan yang berkesinambungan yang diberikan pada ibu dapat mendeteksi dini adanya komplikasi yang dapat terjadi dan juga dapat mencegah kemungkinan komplikasi yang akan terjadi dengan segera. Dengan demikian dilakukannya perawatan Continuity of Care ini mampu menurunkan angka kejadian sectio caesarea. Selain itu melakukan pelayanan Continuity Of Care menciptakan terjalinnya hubungan yang baik antara seorang pasien dan 
bidan. Asuhan yang berkelanjutan berkaitan dengan kualitas pelayanan dari waktu kewaktu yang membutuhkan hubungan terus menerus antara pasien dengan tenaga kesehatan (Kemenkes, 2016). Pernyataan-pernyataan diatas didukung oleh penelitian Rahmawati, 2015 yang berjudul "Asuhan Berkesinambungan Untuk Meningkatkan Kesehatan Ibu dan Bayi di Kabupaten Subang". Dalam penelitian tersebut dijelaskan bahwa untuk meningkatkan kesehatan ibu dan bayi maka dilakukanlah continuity of care ini, pada penelitian tersebut bahkan dijelaskan bahwa asuhan berkesinambungan dilakukan sejak masa remaja dan sebelum kehamilan. Hal tersebut dilakukan untuk mendeteksi dini kelainan atau komplika si yang mungkin terjadi kelak, jika ditemukan kelaianan maka dapat segera ditangani sedini mungkin. Oleh karena itu dengan dilakukannya continuity of care iini maka kesehatan ibu dan bayi dapat meningkat serta kejadian sectio caesarea dapat menurun.

Dari uraian diatas, peneliti tertarik melakukan penelitian mengenai pengaruh continuity of care terhadap kejadian sectio caesarea di Kabupaten Malang

\section{METODE}

Jenis penelitian yang digunakan pada penelitian ini .merupakan penelitian experiment dengan desain penelitian quasi experimental. Penelitian ini bertujuan untuk mengetahui pengaruh continuity of care terhadap angka kejadian Sectio Sesarea di Kabupaten Malang.

Populasi yang digunakan pada penelitian ini adalah ibu hamil yang ada di Kabupaten Malang. Sampel yang diambil dalam penelitian ini adalah 2 kriteria yaitu kriteria insklusi dan eksklusi. Kriteria insklusi adalah ibu hamil trimester III yang bersedia menjadi responden dan ibu hamil fisiologi. Kriteria ekslusi adalah ibu hamil dengan resti. Jumlah populasi penelitian ini adalah sebanyak 18 responden.

Teknik pengambilan sampel yang digunakan pada penelitian ini adalah menggunakan purposive sampling yaitu dengan pengambilan sampel yang sesuai dengan criteria inklusi dan eksklusi. Dan data dikumpulkan dengan menggunakan metode wawancara, observasi, dan pengisian cheklist.

\section{HASIL DAN PEMBAHASAN}

Pada bab ini akan diuraikan mengenai hasil analisis data yang telah dikumpulkan oleh peneliti. Data yang telah dikumpulkan berjumlah 18 orang. Data yang diperoleh adalah data mengenai Pengaruh Continuity Of Care Terhadap Angka Kejadian Sectio Caesarea Di Kabupaten Malang pada tahub 2018, penelitian dilakukan dalam rentang wakktu dari bulan Maret-Agustus 2018.

Analisa data pada penelitian ini terdiri dari data umum dan khusus. Pada data umum akan diketahui hasil tentang data responden berdasarkan umur, pekerjaan, paritas dan pendidikannya. Adapun data khusus dilakukan untuk melihat hubungan antara pemberian continuity of care terhadap kejadian sectio caesarea di wilayah Kabupaten Malang. Berikut data umum dari penelitian ini 
Tabel 1. Karakteristik Responden Berdasarkan Umur

\begin{tabular}{ccc}
\hline \multicolumn{1}{c}{ Usia } & Jumlah & Persentase \\
\hline$<20$ tahun & 2 & $11 \%$ \\
$\geq 20-\leq 35$ tahun & 15 & $83 \%$ \\
$>35$ tahun & 1 & $6 \%$ \\
\hline \multicolumn{1}{c}{ Total } & 18 & $100 \%$
\end{tabular}

Berdasarkan penelitian karakeristik umur ibu hamil mayoritas berusia $\geq 20-\leq 35$ tahun berjumlah 15 responden $(83 \%)$ dan minoritas yang berusia $>35$ tahun berjumah 1 responden (6\%). sesuai dengan pendapat Kemenppa RI (2016) menyatakan bahwa reproduksi sehat optimal bagi seorang wanita berada pada usia 20-35 tahun karena dalam usia tersebut organorgan reproduksi berfungsi secara optimal dengan siklus menstruasi.

Tabel 2. Karakteristik Responden Berdasarkan Pekerjaan

\begin{tabular}{|c|c|c|}
\hline Pekerjaan & Jumlah & Persentase \\
\hline [bu Rumah Tangga & 14 & $78 \%$ \\
\hline Bekerja & 4 & $22 \%$ \\
\hline Total & 18 & $100 \%$ \\
\hline
\end{tabular}

Tabel 2 menunjukkan bahwa sebagian besar ibu hanya sebagai Ibu Rumah Tangga berjumlah 14 responden (78\%) dan sebagian kecil yang bekerja berjumlah 4 responden (22\%). Peneliti mengkaji karena ini berhubungan dengan sosial ekonomi yang akan mempengaruhi kesehatan fisik maupun psikis

Tabel 3. Karakteristik Responden Berdasarkan Pendidikan

\begin{tabular}{lccc}
\hline \multicolumn{2}{c}{ Pendidikan } & Jumlah & Persentase \\
\hline SD-SMA & 16 & $89 \%$ \\
Sarjana & Total & 2 & $11 \%$ \\
\hline \multicolumn{2}{c}{ Tor } & 18 & $100 \%$ \\
\hline
\end{tabular}

Tabel 3 menunjukkan bahwa sebagian besar pendidikan ibu adalah SD-SMA dengan jumlah 16 responden (89\%) dan sebagian kecil yang berpendidikan sarjana berjumlah 2 responden (11\%). Ibu yang berpendidikan menengah keatas, memiliki pengetahuan yang cukup sehingga lebih mudah menangkap informasi termasuk pengetahuan tentang pentingnya continuity of care dalam menghadapi proses persalinan. Sehingga diharapkan kondisi ibu menjadi lebih baik. Sesuai dengan pendapat Rahmawati (2018) menyatakan bahwa semakin tinggi tingkat pendidikan seseorang akan semakin mudah dia menyerap informasi yang diterima. 
Tabel 4. Karakteristik Responden Berdasarkan Paritas

\begin{tabular}{cccc}
\hline & Pekerjaan & Jumlah & Persentase \\
\hline Primipara & & 12 & $67 \%$ \\
Multipara & & 6 & $33 \%$ \\
\hline \multirow{2}{*}{ Total } & 18 & $100 \%$ \\
\hline
\end{tabular}

Berdasarkan data dari tabel 4 bahwa sebagian besar respoden merupakan kehamilan primipara dengan jumlah 12 responden (67\%) dan sebagian kecil merupakan kehamilan multipara berjumah 6 responden (33\%). Pengalaman ibu bersalin dapat mempengaruhi kebutuhan ibu akan pendampingan saat melahirkan. Hal ini sesuai dengan teori Richard dan Diane (2009) bahwa keadaan psikologis ibu akan mempengaruhi proses persalinan sehingga dibutuhkan dukungan dari seorang suami, keluarga dan tenaga kesehatan minimal berupa sentuhan dan kata-kata pujian yang dapat membuat nyaman, memberi penguatan, meningkatkan keharmonisan keluarga, dan pendampingan selama kehamilan.

Selanjutnya adalah hasil penelitian dari data khusus

Tabel 5. Responden Yang Diberikan Continuity of Care

\begin{tabular}{ccc}
\hline Jenis Persalinan & Jumlah & Persentasi \\
\hline Dilakukan Continuity of Care & 18 & $100 \%$ \\
\hline Total & 18 & $100 \%$ \\
\hline
\end{tabular}

Tabel 5 menunjukkan bahwa seluruh responden mendapatkan Continuity of Care berjumlah 18 orang $(100 \%)$.

Tabel 6. Jenis Persalinan Responden Yang Diberikan Continuity of Care

\begin{tabular}{|c|c|c|}
\hline Jenis Persalinan & Jumlah & Persentase \\
\hline Normal & 17 & $94 \%$ \\
\hline Sectio Caesarea & 1 & $6 \%$ \\
\hline Total & 18 & $100 \%$ \\
\hline
\end{tabular}

Tabel 6 menunjukkan bahwa sebagian besar jenis persalinan normal berjumlah 17 responden (94\%) dan sebagian kecil merupakan persalinan Sectio Caesarea berjumah 1 responden $(6 \%)$.

Tabel 7. Pengaruh Continuity of Care Terhadap Jenis Persalinan

\begin{tabular}{|c|c|c|}
\hline Jenis Persalinan & Dilakukan Continuity of Care & $\mathbf{p}$ \\
\hline Normal & 17 & 0.03 \\
\hline Sectio Caesarrea & 1 & \\
\hline
\end{tabular}

Total 18

Berdasarkan tabel 7 dapat dilihat bahwa sebagian besar jenis persalinan yang Dilakukan Continuity of Care jenis persalinannya adalah normal berjumlah 17 responden (94\%) dan sebagian kecil merupakan persalinan Sectio Caesarea berjumah 1 responden (6\%) dengan nilai $\mathrm{p}$ value 0.03 , yang menunjukkan bahwa terdapat hubungan yang signifikan antara pemberian intervensi Continuity of Care terhadap persalinan normal. 


\section{KESIMPULAN}

Dengan dilakukannya continuity of care sejak masa kehamilan didapatkan hasil bahwa perlakuan tersebut berhasil menurunkan angka kejadian sectio caesarea di Kabupaten Malang. Hal ini terbukti bahwa sebanyak 18 responden (100\%) mendapakatkan perlakuan continuity of care. Sebanyak 17 responden (94\%) bersalin dengan normal pervaginam dan 1 responden $(6 \%)$ bersalin dengan sectio caesarea. Dengan demikian continuity of care yang dilakukan sejak masa kehamilan hingga keluarga berencana selain dapat menurunkan angka kejadian sectio caesarea tapi juga dapat meningkatkan derajat kesehatan ibu dan bayinya.

\section{DAFTAR PUSTAKA}

Aprina, A. P. (2016). Faktor-Faktor yang Berhubungan dengan Sectio Caesarea di RSUD DR. H. Abdul Moeloek Provinsi Lampung. jurnal Kesehatan , 7(1): 1-7.

Asrinah, Putri, S.S., Sulistyorini, D., Muflihah, I.S., Sari, D.N. (2010). Asuhan Kebidanan Masa Kehamilan. Yogyakarta: GRAHA ILMU.

Davies, L., \& Mc Donald, S. (2011). Pemeriksaan Kesehatan Bayi: Pendekatan Multidimensi. Jakarta: EGC.

Depkes. (2014). Jadilah Kartini Indonesia Yang Tidak Mati Muda (Pencanangan Kampanye Peduli Kesehatan Ibu 2014). Jakarta: Depkes.http://www. depkes.go.id

Depkes.(2013). Profil Kesehatan Indonesia. Jakarta: Depkes. http://www.depkes.go.id

Hutahaean, S. (2013). Perawatan Antenatal. Jakarta: Salemba Medika Jannah, N. 2014. ASKEB II Persalinan Berbasis Kompetensi. Jakarta: EGC

Kementerian Pemberdayaan Perempuan dan Perlindungan Anak (Kemenppa). (2016). Wanita Perlu Pahami Kesehatan Reproduksi.

Lailiyana, Laila, A., Daiyah, I., Susanti, S. 2011. Buku Ajar Asuhan Kebidanan persalinan. Jakarta: EGC.

Leveno. (2009). Paduan Ringkas Obstetri Williams Edisi 21. Jakarta : EGC.

Mandriawati,G.A. (2012). Asuhan Kebidanan Antenatal. Jakarta: EGC. 
Marmi, \& Rahardjo. (2012). Asuhan Neonatus, Bayi, dan Balita dan Anak Prasekolah. Yogyakarta: Pustaka Pelajar.

Manuaba, I. A. C., Manuaba I. B. G., \&Manuaba I. B. G. F. (2012). Ilmu Kebidanan, Penyakit Kandungan, Dan KB Untuk Pendidikan Bidan. Jakarta : EGC

Nugroho, T., Nurrezki.,Wrbaliza, D., Wilis. 2014 .Buku Ajar Asuhan Kebidanan Nifas. Yogyakarta: Nuha Medika

Nuraisiah, A., Rukmawati, A., Badriah, D.L. 2014. Asuhan Persalinan Normal Bagi Bidan. Bandung: PT Refika Aditama.

Prawirohardjo, S. (2009). Ilmu Kebidanan. Jakarta: PT. Bina Pustaka.

Proverawati, A., Islaely, A.D,. Aspuah, A. (2010). Panduan Memilih Kontrasepsi. Yogyakarta: KDT.

Provil Jawa Timur. (2012). Profil Kesehatan Provinsi Jawa Timur. http://www.google.com

Purwoastuti, Endang, dkk. Asuhan Kebidanan Masa Nifas \& Menyusui. Yogyakarta: Pustaka Baru Press, 2015.

Putra, S,R. (2012). Asuhan Neonatus Bayi Dan Balita Untuk Keperawatan Dan Kebidanan. Jogjakarta: D-MEDIKA.

Rahma,Marliana, 2015. Asuhan Berkesinambungan Untuk Menigkatkan Kesehatan Ibu Dan Bayi Di Kabupaten Subang. Akademi kebidanan Bandung JL. Garuda no 79 Bandung, Indonesia

Rahmawati, R. I. (2018). Hubungan Tingkat Pendidikan Dan Riwayat Antenatal Care (ANC) Dengan Tindakan Sectio Caesarea. 1-10.

Ringkasan Kajian. (2012). Kesehatan Ibu dan Anak. http://www.unicef.org

Saifudin, A.B., Affandi. B., Baharudin. M., Soekis.S., (2011). Buku Panduan Praktis Pelayanan Kebidanan. Jakarta: Yayasan 
Bina Pustaka Sarwono Prawirohardjo Saleha, S. (2009). Asuhan Kebidanan Pada Masa Nifas. Jakarta: Salemba Medika.

Sibogariang, E.E., Pusmaika, R., Rismalinda. (2010). Kesehatan Reproduksi Wanita. Jakarta: TIM

Sondakh, J. J.S. (2013). Asuhan Kebidanan Persalinan Dan Bayi Baru Lahir. Jakarta: Erlangga.

Sudarti. \& Khoirunnisa, E. (2010). Asuhan Kebidanan Neonatus, Bayi, Dan Anak Balita. Yogyakarta: Nuha Medika.

Sulistyawati, Ari.(2009). Buku Ajar Asuhan Kebidanan Pada Ibu Nifas. Yogyakarta: ANDI. Continuity of Care | 129

Sulistyawati, A. \& Nugraheny, E. (2010). Asuhan Kebidanan Pada Ibu Bersalin. Jakarta: Salemba Medika.

Sumarah, Widyastuti, Y., Wiyati, N. (2009). Perawatan Ibu Bersalin. Yogyakarta: Fitramaya.

Tresnawati, F. (2012). Asuhan Kebidanan. Jakarta: PT. Prestasi Pustakaraya.

Wahyuni, S. (2011). Asuhan Neonatus, Bayi, dan Balita. Jakarta: EGC.

Walyani, S.E \& Puwoastuti, E. 2015. Asuhan Kebidanan Persalinan \& Bayi Baru Lahir. Yogyakarta: PUSTAKA BARU PRESS.

Indriati, 2012. Panduan Klinis Paling Komplit Kehamila, Persalinan, \& Perawatan bayi. Jakarta : pelangi Indonesia

Bowers, Cheyne, Mould, Page, 2014. Continuity of care in midwife community. Diakses pada tanggal 18 Desember 2018 pada https://www.ncbi.nlm.nih.gov/pmc/articles/PMC4468794 